\title{
Horticulture in Argentina: a productive alternative with great potential
}

\author{
Ana María Castagnino, María Belén Rosini, Silvia Benson \\ Centro Regional de Estudio Sistémico de Cadenas Agroalimentarias CRESCA, Facultad de \\ Agronomía, Universidad Nacional del Centro de la Provincia de Buenos Aires UNCPBA, Azul, \\ Argentina
}

\begin{abstract}
Horticulture in Argentina is an activity with great potential whose history has mainly been driven by Italian immigrants who arrived during the last two centuries. It is a valuable complement for traditional primary productions on which the country is focused with more than 30 millions of cultivated hectares and different agro-climatic conditions that characterize the different horticultural regions distributed throughout the country. The aim of this article is to give a panorama of the history, reality and perspectives in Argentina of an activity that is an opportunity for producers and entrepreneurs interested in it. Due to its characteristics, horticulture generates and dynamizes employment with great importance for regional economies. The proportion between vegetables and fruit produced and commercialized in Argentina is $63 \%$ and $34 \%$ respectively. Horticultural products for exportation largely are garlic, onion and beans. Concerning the most commercialized vegetables in Argentina, potato, tomato, onion, squash, lettuce, pepper, marrow and sweet potato stand out, whereas orange, tangerine, apple, banana, lemon, pear, grape and grapefruit may be highlighted among fruit. At present, the main challenge of the Argentinian horticultural sector is given not only by the possibilities of productive diversification and the expansion of the productive area but also of the technological level optimization, the application of quality norms and the agro-industry growth.
\end{abstract}

Correspondence: Dr. Ana María Castagnino, Centro Regional de Estudio Sistémico de Cadenas Agroalimentarias CRESCA, Facultad de Agronomía, Universidad Nacional del Centro de la Provincia de Buenos Aires, República de Italia $\mathrm{N}^{\circ} 780$ (7300) Azul, Argentina.

Tel./Fax +54.2281.433291/93-222.

E-mail: amc@faa.unicen.edu.ar

Key words: vegetables, crop, area, regions.

Received for publication: 23 August 2011.

Accepted for publication: 17 November 2011.

(C) Copyright A.M. Castagnino et al., 2011

Licensee PAGEPress, Italy

Italian Journal of Agronomy 2011; 6:e37

doi:10.4081/ija.2011.e37

This work is licensed under a Creative Commons Attribution NonCommercial 3.0 License (CC BY-NC 3.0).

\section{Introduction}

Horticulture in Argentina is an important activity of great social and economic value that represents a valuable complement to the traditional primary productions on which the country is focused.

Although the trend in the area cultivated with vegetables has diminished, the production has grown in the last years due to the incorporation of technological innovations, mainly those applied to productive stages. The expansion of crops in greenhouses, especially in the horticultural belts of big cities can be highlighted, as well as the incorporation of new cultivars and $F_{1}$ hybrids, the optimization of agronomic techniques such as fertilization, irrigation, etc. This allows for self provision of the national market and the exportation of some vegetables such as garlic, onion and beans.

Because of its characteristics, horticulture in Argentina is an activity that generates and dynamizes employment throughout the whole of the chain with great relevance for the regional economies.

The aim of this article is to give a panorama of the history, reality and perspectives of an activity with great potential that is an opportunity for producers and entrepreneurs interested in it in Argentina.

\section{Diffusion of horticulture in Argentina}

Argentina has $2,780,091 \mathrm{~km}^{2}$ (between $22^{\circ}$ and $46^{\circ}$ South latitude) of which around 30 million hectares are devoted to extensive agriculture with a horticultural production of about 500,000 total ha, including 85,000 ha of potato, 3,500 ha of under-cover and 160,000 ha of beans with an approximate total production of 10,000,000 total tonnes (National Agricultural Census) and employing more than 10 million annual day wages, which turns it into an activity of great social value (Ferrato, 2010).

Concerning fruit, the average total cultivated area in the last years is 544,00 0 ha with a total production of 5,499,493 $\mathrm{t}$. In 2001 , the following activities stood out in order of importance: vine growing, nuts (pecan nuts and almonds) and olive trees: 109,500 ha and 376,730 t, citrus trees (orange, lemon, tangerine and grapefruit): 138,000 ha y $2,340,000 \mathrm{t}$; pip fruit (apple and pear) 58,352 ha and 1,867,172 t; stone fruit ( peach and plum): 47,940 ha 538,475 t; subtropical fruit (banana, avocado and mango) 11,400 ha 257,010 $t$ and berries 4,000 ha $16,000 \mathrm{t}$ (Liverotti, 2011).

\section{Brief history}

Commercial horticulture developed through the work done by Italian immigrants that came to the country in three main flows: in the $19^{\text {th }}$ 
century and two in the $20^{\text {th }}$ century, the latter in correspondence with the two World Wars. The later expansion of the sector has had the complementation of immigrants from neighbouring countries such as Bolivia and Paraguay as from the 1990's.

\section{Characteristics and productive diversity}

In Argentina, horticulture is characterized by its great diversity and distribution since in all the country there are horticultural businesses (though of very different sizes) with numerous species and management techniques. Dry-land and irrigated vegetables are produced in the wettest areas as in the centre and north-east areas of the country. Protected cultivations for earlier productions of tomatoes and peppers are mainly concentrated in the provinces of Corrientes, Buenos Aires and Salta.

There is a great diversity of productive strata ranging from small land holding producers to big enterprises but, in general, a limited organization of the sector.

\section{Productive modalities}

Concerning work modalities, the following may be highlighted: the commonly called green belts, specialized horticultural areas and areas of extensive horticulture. In the case of the horticultural belts, they are characterized by productions that take place in family plots or gardens of medium size that surround big cities (7 ha on average). In general, there is a great diversity of crops (10 or more) using a low technological level and lots of handwork. In most cases, they are focused on vegetable productions for fresh consumption and represent the first form of production the country had (in horticoltura). In the case of specialized horticultural areas, these are characterized by the existence of productive enterprises devoted to specific productions, with few crops employing salaried people, in areas where the climate is adequate for those crops. In general they grow earlier productions.

The areas of extensive horticulture comprise larger farms with a high level of mechanization. Their productions are exported (e.g. garlic and onion) or industrialized (potato, peas, tomatoes, corn, etc.). These productions are situated in the Pampean region, Cuyo region (that comprises the provinces of Mendoza and San Juan) and the north-west regions of the country.

Concerning the cultivated species, for their economical importance, a small group holds more than $85 \%$ of the total production value. This is the case of garlic, sweet potato, onion, lettuce, potato, pepper, dry beans, tomato, carrot and pumpkin (MAA, 2007)

\section{Horticultural regions}

Due to its soil-climatic variability, the country can be divided into the following Regions:

Region I or North-west (NOA): comprises the provinces of Salta, Jujuy and Tucuman. This area, mainly in the province of Salta, stands out for the production of dry beans. It also outstands for the earlier productions of tomato, pepper, melon, due to its benign climate. Lots of these are under protected cultivation mainly in Salta and Jujuy. Strawberry, pepper for paprika, sweet potato, early onions, melon, pumpkin and carrot are also produced here.

Region II or North-east (NEA): comprises the provinces of Chaco and Formosa. It is an area in which horticulture has a lower expansion, it is also devoted to the earlier field productions such as sweet corn, pumpkin, tomato and marrow, and to the earlier greenhouse productions such as tomato, pepper, melon, cucumber and beans. It is complementary to more important areas of earlier production in the country.

Region III or Mesopotamia: is the main area of earlier productions of tomatoes, peppers and eggplants. It comprises the provinces of Misiones, Corrientes and Entre Rios and it is characterized by its wet climate.

Region IV or Andean: it is an area characterized by mild continental climate and very good sanitary conditions because of very low rainfalls (300 mm per year or less). Open field vegetable crops such as garlic, onion, melon, pepper for paprika, processing tomato for obtaining dehydrates and tinned tomatoes outstand in this region, which comprises the provinces of La Rioja and Catamarca.

Region V or Central: it is formed by the provinces of Cordoba, San Luis and Santiago del Estero, characterized by mild continental climate and variable rainfalls between 300 and $700 \mathrm{~mm}$ per year. It produces mainly earlier field fruits: potato, sweet potato and pink garlic as well as green beans and beans for dry grains, chickpea, leaf vegetables, processing tomato, carrot, onion, pumpkin, etc.

Region VI or Cuyo: it comprises the provinces of Mendoza and San Juan. It stands out for the intensive production of field irrigated vegetables. It is one of the most important region for the production as garlic (white and pink), onion, carrot, pumpkin, potato, among others and also for the production of processed vegetables: tinned (especially tomatoes) and dehydrates. This region also stands out for the production of vegetable seeds. It has a mild dry climate with rainfalls of 100 to $300 \mathrm{~mm}$ per year and irrigation using water from thawing.

Region VII or Litoral: it comprises the provinces of Santa Fe and Buenos Aires. It is an area of great volume and diversity of vegetable productions. The horticultural belts of La Plata, Buenos Aires and Mar del Plata stand out for their production of under-cover tomatoes, leaf vegetables and peppers. Field production of numerous species, such as artichoke, spinach, leek, lettuce, strawberry etc., is also accomplished. In the south-east of the Buenos Aires province, the production of potato and lettuce is significant. The main area of onions production can be found in the south of the Buenos Aires province. In the province of Santa Fe, the production of peas and lentils is important. Concerning agro-industry, this area has different enterprises devoted to the frozen vegetables.

Region VIII or West: it comprises the provinces of La Pampa, Neuquen and Rio Negro. It is characterized by its mild-cold dry climate with very cold winters and rainfalls of 200 to $400 \mathrm{~mm}$ per year. Onion, garlic, potato, processing, pepper, carrot and celery crops are grown here. A distinctive aspect is given by the building of irrigation furrows from the Negro and Colorado rivers, which allowed for the creation of one of the most important poles of intensive regional development in the country such as the Alto Valle of Rio Negro.

Region IX or Patagonia: it is the most southern region of the country and comprises the provinces of Santa Cruz, Chubut and Tierra del Fuego. It is a region of cold climate with a short free-of-frost period. It is characterized by the production of cabbage, cauliflower, lettuce, chard and spinach for regional self consumption.

\section{Horticultural production and exportation}

Argentina generates more than $\mathbf{5 0 0}$ million dollars in horticultural exportations mainly of fresh vegetables (93\%) and the rest (7\%) of processed ones (Senasa, 2008). Around $93 \%$ of the national production of vegetables is for the internal market and 7\% is exported.

Three crops, beans, garlic and onion, represent $97 \%$ of the value of exported vegetables. In the last years, the exportation of other vegetables, such as strawberry, pumpkin, carrot and potato, has increased. 
The main destination of exportations is Brazil, followed by the European Union countries and neighbouring countries as Uruguay and Chile. Argentina has a tradition of exportation of beans. At present, 133,795 ha are sown corresponding to $151,000 \mathrm{t}$ (Ferrato, 2010).

It is the second world exporter of garlic; 120,500 t/year of red white garlic are produced, thus participating with $1 \%$ of the sown area and production. Onion represents $16 \%$ of the Argentinian horticultural exportations. Ninenty percent of the national production is consumed fresh and is commercialized in wholesale markets, fruit-shops and hypermarkets; the remaining $10 \%$ is industrialized. The main destiny is the conserving industry, though what is derived from the frozen and dehydrated industry should also be highlighted and at a lower scale, pickling and grinding. According to data of the Buenos Aires wholesale market, main reference concerning the volumes of fruit and vegetables commercialized in Argentina between 2005 and 2010, the vegetables commercialized surpassed the fruit (62.57 and $37.43 \%$ respectively) with the total volumes of the main vegetables: 4,912,529.2 tn and of the main fruit 2,939,230 tn (Liverotti, et al., 2011). In vegetables, in the mentioned period in tn year-1: potato, 37,241(a); tomato, 122,415(b); onion, 106,777(b); squash, 63,354(c); and, finally lettuce, pepper, marrow and sweet potato, 27,873;20,344; 19,274 and 17,848(d) stand out, whereas, in fruit, orange, 119,300(a); tangerine, 84,615(b); apple, 83,907(bc); banana, 78,153(c).

Concerning the trends in consumption in that period: in fruit it was increasing for tangerine, banana and pear, and in vegetables for melon, whereas it was decreasing for orange, apple, grapefruit, lemon and peach and in vegetables: lettuce, potato, onion, sweet potato, pepper, carrot and squash.

Concerning total volumes in tn. year ${ }^{-1}$ in vegetables in 2005: 105,612 (a), followed by 101,168 in 2006; 90,330 in 2008 and (in 2007) 89,539(ab); finally, in 2009 and in 2010, 87,954 and 86,491(b), respectively. In fruit, in $2005,61,568.8$ (a); followed by (2006) 59,354; (2009) 58,003 and (2010) $56,957(\mathrm{ab})$ stood out, with a lower total volume in 2008 and 2007, 55,291 and 55,276(b), respectively. Although the annual trend should accompany the growth in population and consumption, the decreasing total volumes, may be due to the incidence of the opening of new markets.

\section{Situation, social relevance and perspectives of Argentinian horticultural agri-food chains}

According to FAO and the latest National Agricultural Census, whose data have been published (CNA, 2002), the production of Argentina is 10.5 millions of tonnes approximately. Although Argentina at present self supplies most of the vegetables consumed, it has an enormous potential for the productive expansion, not only of the traditionally grown vegetables such as onion, garlic, beans, potato, tomato, but also of other not very much consumed species such as asparagus. Perspectives for national organic horticulture are promising, too.

\section{Sector opportunities}

Present opportunities of the Argentinian horticultural sector are given not only by the possibilities of expansion of the productive area and productive diversification, but also by the optimization of the technological level, the application of quality standards and the expansion of agro-industry and associationism. In order to obtain this, the generation and implementation of concrete strategies among producers, groups of producers together with institutions and the compromise of all the members of the Horticultural Agri food Chain is required.

In conclusion, it is an activity that provides great added value. Although it occupies a smaller area than other agricultural activities, it has a great potential and represents an opportunity for producers and entrepreneurs of the country and abroad interested in this activity.

\section{References}

Ferrato J, Rodríguez Fazzone M, 2010. Buenas prácticas agrícolas para la agricultura familiar. Cadena de las principales hortalizas de hojas en Argentina. Ministerio de Agricultura, Ganadería y Pesca de la Nación/FAO Ed., Argentina.

Castagnino AM, Diaz K, Rosini MB, Sasale S, 2009. Manual de cultivos hortícolas innovadores. Una herramienta para la docencia universitaria y la difusión de nuevas alternativas productivas. Hemisferio Sur SA Ed., Buenos Aires, Argentina.

Liverotti 0, Zubiría A, Castagnino AM, Díaz KE, Rosini MB, 2011. Evolución de los volúmenes de ingreso al MCBA de las principales especies hortícolas y frutícolas en el período 2005-2010. Proc. 34rd Nat. Congr. de Horticultura on "El arte de integrar la producción y el consumo. Visión actual y futura”, 27-30 September 2011, Buenos Aires, Argentina.

MAA, 2007. Nuestra provincia, nuestro campo: El sector agropecuario de la Pcia. de Bs As. Ministerio de Asuntos Agrarios de la Pia. de Bs. As. Ed., Buenos Aires, Argentina.

Ministerio de Agricultura, Ganaderia y pesca de la Nación, 2010. Producción Hortícola: en la mesa de todos. Available from: http://www.alimentosargentinos.gov.ar/0-/revistas/r_33/articulos/ mesa_todos.htm

Servicio Nacional de Sanidad y Calidad Agroalimentaria, 2008. Available from: www.senasa.gov.ar 